\title{
Rевеавсн автісік: Entrepreneurship development of tribal women in Bastar district of Chhattisgarh
}

\author{
GOPAL KRISHNA ACHARYA, RAVI SHREY, AKHILESH PANDEY, \\ MITHILESH PANDEY AND ROHIT DWIVEDI
}

Article Chronicle :

Received :

19.07.2017;

Accepted :

03.08.2017

\section{KEY Words : \\ NTFPs, Entrepreneurship development, Tribal women, Cottage industry}

JEL codes:Q13, Q23, J16, O13, P25, R11

Author for correspondence : GOPAL KRISHNA ACHARYA Department of Agricultural Economics, Indira Gandhi Krishi Vishwavidyalaya, RAIPUR (C.G.) INDIA Email : gopalkrishnaacharya@ rediffmail.com

See end of the article for authors' affiliations
SUMMARY : This paper aims to examine and study the entrepreneurship skills of the tribal women involved in NTFP collection and marketing in Bastar district of Chhattisgarh. Bastar district is endowed with dense forest covering $75.54 \%$ of the total area with abundant resource of economically important non-timber forest products. $80 \%$ NTFPs gatherers are women and out of those $55 \%$ women belongs to age group of 18-30 years, and 53\% of the women were illiterates in the study area. The average labour days involved in the collection was 134.33 per annum per household and $68.23 \%$ women were involved in collection followed by men and children at $19.29 \%$ and $12.48 \%$ respectively. On an average Rs. 20258.69 per household per annum were generated through the selling of NTFPs, which is majorly contributed by women collectors with 65.62 per cent followed by 23.01 and 11.37 per cent by male and children collectors respectively. The labour employment indicated that 80.85 per cent women were involved in processing of NTFPs and only 19.15 per cent men were contributing them. The contribution of women in marketing of NTFPs in contrarily less and they sell only 27.56 per cent and rest 72.44 per cent are sold by men. The profit margin obtained after processing is $53.79 \%$ instead of selling unprocessed is only $44.25 \%$. On an average the highest profit margin after reducing the processing cost gained through Kalmegh with 65.40 per cent followed by Cashew nut, Tamarind, Tikhur, Chironjee and Mahua with 51.26, 44.71, 42.23, 32.75, and 29.79 per cent respectively. Although the scenario looks satisfactory but still there is scope because the producer's share in consumer rupee is very less ranging from 53-54 per cent, which may rise upto 85-95\%, if proper guidance and training provided to enhance women's marketing skill to grow their cottage industries and at the same time teaching them time-saving and sustainable methods to harvest NTFPs which also may protect the ecosystem.

How to cite this article, Acharya, Gopal Krishna, Shrey, Ravi, Pandey, Akhilesh, Pandey, Mithilesh and Dwivedi, Rohit (2017). Entrepreneurship development of tribal women in Bastar district of Chhattisgarh. Agric. Update, 12(TECHSEAR-7) : 1923-1926; DOI: 10.15740/HAS/AU/12.TECHSEAR(7)2017/1923-1926. 